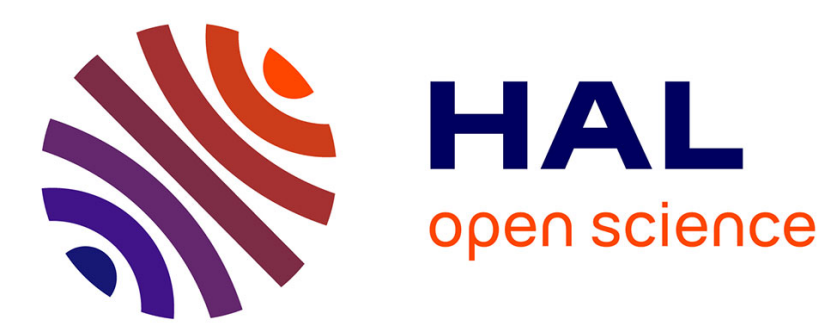

\title{
Firm-Market equivalency: determinants and effects on industry dynamics
}

\author{
Elena de Vogeleer, Denis Lescop
}

\section{To cite this version:}

Elena de Vogeleer, Denis Lescop. Firm-Market equivalency: determinants and effects on industry dynamics. ENEF 2012: 9th European Network on the Economics of the Firm meeting, Sep 2012, Bologne, Italy. hal-02408568

\section{HAL Id: hal-02408568 https://hal.science/hal-02408568}

Submitted on 13 Dec 2019

HAL is a multi-disciplinary open access archive for the deposit and dissemination of scientific research documents, whether they are published or not. The documents may come from teaching and research institutions in France or abroad, or from public or private research centers.
L'archive ouverte pluridisciplinaire HAL, est destinée au dépôt et à la diffusion de documents scientifiques de niveau recherche, publiés ou non, émanant des établissements d'enseignement et de recherche français ou étrangers, des laboratoires publics ou privés. 


\title{
Firm/Market Equivalency: Determinants and Effects on Industry Dynamics
}

\author{
Elena De Vogeleer Denis Lescop \\ Telecom Ecole de Management \\ 9 rue Charles Fourier, 91011 Evry Cedex France \\ elena.de_vogeleer@telecom-em.eu, denis.lescop@telecom-em.eu
}

\begin{abstract}
Today's firm is a complex nexus of interactions, which it facilitates and regulates; it supports market activity by providing participants with basic resources. Market failures form the foundation of this phenomenon; they create business opportunities that firms address through market support strategy. This paper explores the phenomenon of concurrent double function of firm: market creation and market support, through the concept of firm/market equivalency. We define firm/market equivalency as a platform-based cohort founded on mutually beneficial cooperative interactions between platform leader and firms-satellites, that gravitate towards the platform leader, subject to certain conditions. We address firm/market equivalency through its determinants (control and governance, capitalization, and interaction type). We then apply these concepts to a case study and discuss implications of firm/market equivalency for antitrust policy.
\end{abstract}

Keywords: firm/market equivalency multi-sided markets platforms

JEL Classification: L10, L22.

\section{Introduction}

Firms have evolved. Now they are able to project a high degree of attraction on other economic players. Firms like Google, eBay, Apple, Microsoft, Sony, and P\&G create complex, environment-enriching networks of partners, complementors and collaborators around them. Numerous collaborative architectures sustain this phenomenon: platforms, business ecosystems, crowdsourcing, connect \& develop, open innovation, clusters, as well as living labs. 
Markets have evolved. Market construction, evolution and transformation entail movements of resources, knowledge and innovations. One of the essential functions of companies lies in their capacity to create markets: this function ensures the adaptability of the system and its survival, as well as the optimal use of scarce resources. It also allows the emergence of innovations, technological breakthroughs and new forms of development of our society.

The process of competition is changing and a new mode of competitive pressure emerges: firms use strategic partnerships and third-party players, aiming to enhance their competitive and economic power. The firm is no longer this simplistic black box as described by the neoclassical economic theory. Today it is a complex nexus of interactions and relationships. The firm acts as a facilitator and a regulator of the overall system, providing bare necessities for collaboration, and it does so with a strategic intent. In this sense, firms can model their environment and their market to their liking. They can influence the rules of the competitive game within an industry in order to improve the market conditions and architecture. Rather than simply creating markets, the firms can now also support them.

Google is one typical example of these evolutions. Since the birth of the Internet and proliferation of Web pages and online content, the need to browse, seek, and find led to the emergence of the online search engines. Over fifteen years ago Google outstripped its competitors by its ability to complete keyword-based search queries and rank the resulting countless web pages in the order of relevance. Within few seconds Google's algorithm responds to the visitor's request: it's Magic by Design, to quote Thomas A. Stewart (2008). But this apparent magic is only the visible part of Google. The success of the search engine was built on its reputation, the experience provided to the consumers, the bizarre name so easy to remember, its management, its innovations, the strength of its technology, its network of partners. Its model is based on indirect network externalities: the number of visitors on the platform (search engine) is the basis of the virtuous spiral. Anything that will help to increase and capture the attention of the final consumer is monetized on the advertising side of the market. It is noteworthy that Google attracts thousands of developers to its platform with its decentralized and collaborative innovation model, aimed at reinforcing the value of its platform through ongoing innovation. Its economic model is a typical platform-based case of a two-sided market.

Just like Google, eBay, Apple, Microsoft, Sony, and P\&G, some firms project a high degree of attraction onto other economic players. Such key- 
stone firms are able to create complex, environment-enriching networks of partners and collaborators around them. Numerous collaborative structures sustain this phenomenon: platforms, business ecosystems, crowd-sourcing, connect \& develop, open innovation, clusters, as well as living labs.

Numerous academic works have analyzed this new form of industrial organization. The economics literature identifies the phenomenon as multi-sided markets. It has largely focused on the pricing issue in multi-sided markets (Armstrong (2006), Rochet and Tirole (2003, 2006), Rysman (2009), Weyl (2010)). The management literature refers to business ecosystems (Moore $(1993,1996))$ and platforms (Cusumano (2010), Gawer (2009)). It has largely focused on development and functioning of such systems, as well as on the role of the central firm and small niche players. Some authors (Iansiti and Levien (2004), Evans et al. (2006)) studied the emergence of business ecosystems through platform strategies. Our work follows these strands of literature and proposes a conceptual framework that integrates these two strands.

Our work is conceptual. Section 2 studies the theoretical foundation of the phenomena: market failure and market creation. We argue that market failures create business opportunities that firms address through the platform or intermediary strategy. Section 3 defines the concept of firm/market equivalency and discusses its determinants: control and governance of the system, capitalization (value capture), and interaction types. In section 4, we present a case study of the entry of Apple in the mobile sector, using our framework. Section 5 concludes the paper by outlining some implications of firm/market equivalency for antitrust policy.

\section{Market Failure and Market Creation}

In the ideal world of classical economic theory the invisible hand leads the market to efficiency. Such theoretical market structures ensure the exhaustion of all possible mutually profitable transactions. Nevertheless as far back as in the late 1950s Bator (1958) stated:

Many things in the real world violate such correspondence: imperfect information, inertia and resistance to change, the infeasibility of costless lump-sum taxes, businessmen's desire for a 'quiet life', uncertainty and inconsistent expectations, the vagaries of aggregate demand, etc. 
In other words, some market institutions may be unable to support desirable economic activities or to avoid obsolete ones.

Nearly two decades later Williamson (1975) offered a new interpretation of this argument and developed three conditions that, alone or in combination, give rise to market failures:

1. Bounded rationality of economic agents: in complex or uncertain environment, economic agents make wrong choices because of their misunderstanding of the situation or because of their attitude towards risk. Bounded rationality therefore leads to market inefficiencies.

2. Opportunistic behavior: it emerges in markets with a limited number of buyers or sellers. Collusive agreements or cartels are examples of market failure related to opportunistic behavior. They can block or delay new technologies, or simply impede the entry of more efficient competitors.

3. Imperfect information: it weakens the decision-making process. Information asymmetries or incomplete information induce market inefficiencies by impeding profitable transactions or by lessening strategic choices.

Market failures hence create untapped opportunities of mutually profitable exchanges and innovations. In a sense, they demonstrate the inability of the productive system to reach efficiency, either by inadequate business models or by inadequate market structures. Myopia of economic agents (condition 1) and their attitude towards risk give rise to difficulties in understanding medium to long term consequences of strategic behavior. Economic agents then make use of standardized and generic strategies (condition 2). Many economic players are followers and very few are visionary. In addition, even if opportunities arise, stakeholders' risk aversion slows down the decision-making and sometimes results in project delays.

The inability of economic agents to interact properly and to complete all mutually profitable exchanges as a result of inefficient market organization is neither market-bound, nor industry-specific. Hence, it may lead to failures at the highest level of the economic system: economic agents are not aware of the existence of profitable exchanges and innovation opportunities outside their markets.

Dundas and Richardson (1980) suggested: 
Entrepreneurs exploit market failures, although how entrepreneurs identify these remains unstudied [...]. The small single product firm typically comes into existence to exploit a particular class of market failure. The entrepreneur has special skills (finance, technical or market-related), which enable him to do what markets have thus far failed to do, or to out-perform competitors, if they exist.

Unfortunately, the awareness of some managers is not sufficient to evangelize their strategic intent with the various stakeholders: shareholders, investors (including banks), employees, and even top management are often reluctant to radical changes in business models (conditions 1 and 3) and prefer a conservative strategy preserving the positioning of the company (condition 2).

Markets evolve. The companies that were the most dynamic in the beginning of the last century are different from the ones today. Economic history shows that markets are built, and then evolve and transform entailing movement of resources, knowledge and innovations. One of the essential functions of companies lies in their capacity to create markets: this function insures the adaptability of the system and its survival, as well as an optimal use of scarce resources. It also allows the emergence of innovations, technological breakthroughs and new forms of development of our society.

The question is how to create a market? That is, how to create a place, either physical or virtual, where suppliers offer products or services to other economic agents. Three conditions characterize the existence of a market. First condition is the presence of two types of economic agents, namely buyers and sellers. Second, these economic agents must have a need to interact. Third, the interaction should be mutually profitable. The market also supports sharing and diffusion of innovations, knowledge and competences to sustain the performance of its companies.

As a coordinating institution of economic agents, a market also performs functions of information diffusion and exchange facilitation. The information function is essential to avoid the third market failure condition. A market does not appear spontaneously but is an institution deliberately constructed and organized by some economic agent performing a role of intermediary. To function properly markets need rules: mechanism for allocation of products and services, terms of exchange, a system of comparison of value and transactions (which would eventually evolve into a pricing system). 
Auctions are one example of intentional market creation by an economic agent: they make up for the absence of markets in certain circumstances or in the presence of market failures (small number of providers or consumers, low competitive pressure, specific demand, etc.). Cassady (1967) described multiple forms of auctions used throughout the world dating back to four centuries before Christ. Nowadays, auctions are still used, but a new type of market creation appears through platform strategies.

\section{Firm/Market Equivalency and its Determinants}

A platform can be perceived as a locus of support that facilitates interactions - or transactions - between several groups of economic agents. A platform can take a number of incarnations with reference to both the tangibility of presence and the time parameter: physical, such as a concert hall, a shopping mall, or a fair; virtual, such as eBay or Amazon; permanent, as is the case with the stock markets; or single-instance, as is the case with the calls for tender. Emergence of a platform relies on the need to coordinate the economic agents and thus on the existence of market failures. Platforms are responsible for the creation of links between various groups of economic agents. These links can either be economic, social or commercial.

The economics literature refers to this functional compilation as multisided markets (Armstrong (2006), Rochet and Tirole (2003, 2006)). However, this terminological cross-reference is inherently confusing since all markets in their essence are multi-sided; e.g. as is the case with two-sided markets, being a subset of multi-sided markets, one side is typically the sellers, while the other side is the buyers. Recently, Rysman (2009) argued that the existence of a multi-sided market is tied more to the company's strategic intent than to the market's intrinsic structure:

As this distinction often depends on the decisions of the intermediary rather than on purely technological features of the market, it may be better to use the term 'two-sided' strategy rather than 'two-sided market'.

The most topical examples of multi-sided strategies are the free daily newspapers, free TV channels, eBay, and the Google search engine. These companies create links between different players in different markets. They promote the financing of a product or a service in one market by engaging another player 
in another market: e.g. in exchange for exposure to an audience the advertisers are funding free daily newspapers. This phenomenon pertaining to the services which are apparently free is quite widespread throughout the Internet and media markets. The use of multi-sided strategies allows companies to find new ways to recognize and capture business opportunities and innovation.

The management literature refers to this concept as business ecosystems (Moore $(1993,1997))$. The literatures defines this term as intentional communities of economic actors whose individual business activities share in some large measure the fate of the whole community (Moore (2006)). The definition covers a wide range of different economic situations. Iansiti and Levien (2004) have shown the crucial role of a central firm and niche players in the survival and dynamics of business ecosystems. This central firm can affect the overall systems in two ways: as a member of the business ecosystem, and hence exerting some competitive pressure onto other members of the ecosystem, and as an intelligent biotope providing the other participants with elementary building blocks, such as competences, knowledge, information, database, etc... in order to sustain their economic activity. The regulatory power of the system relies on the latter role: as an intermediary, the central firm regulates and controls its business ecosystem, and proposes a vision of the market. Moore (2006) stated:

Just as the firm internalized markets under the visible hand of the entrepreneur, the ecosystem form internalizes systems of firms and the markets that connect them under the guiding hands of community leaders. In a business ecosystem, the leaders of a multitude of firms come together around a broad vision of a future they want to make happen. They understand that establishing this future will require both cooperation and competition among firms.

This intermediary role is often played through a platform strategy. Hence, business ecosystems, platforms and multi-sided markets refer to the same phenomenon: companies performing the function of a market as a result of a market failure. To avoid confusion, we will refer to this situation as firm/market equivalency.

Moreover, a platform can be seen as a medium that facilitates interaction or exchange between at least two sides of a market, and which was either created or formed spontaneously as a result of a market failure. In this 
context, firm/market equivalency refers to a platform-based cohort founded on mutually beneficial cooperative interactions between the platform leader and firms-satellites that gravitate towards the platform leader, given that the platform leader is the market creator who exercises control over its satellites and capitalizes on the interactions that take place.

The firm/market equivalency condition does not imply that the boundaries of the firm and the market coincide. Rather, it refers to a firm, which supports the market activity by providing market players with basic resources such as knowledge, know-hows, standardization, interoperability and rules. However, a firm cannot be regarded as a classical market institution for it is not altruistic. A firm creates a market to enhance its own profitability and survival. Hence, in addition to its market creation function, which does not necessarily concur with functions of providing market support or intermediation, firm/market equivalency requires three key determinants: control and governance of the system (market), capitalization as well as interaction type.

\subsection{The First Determinant: Control and Governance}

The platform owner must provide governance to the system without being overly intrusive. Opportunistic behavior of certain economic agents poses a real danger to the platform's well-being since such behavior can affect the stability of the entire system. The platform then faces a classic principal-agent paradigm. The agents are the partners who join the platform. The principal, affected by the actions of agents, is the platform owner; the principal uses economic agents to improve the performance of its system and increase its profitability and odds of survival. The logic of the platform owner is longterm (including the survival and proper functioning of the entire system), while certain agents (SMEs, small developers) are more likely to adopt the short-term strategies.

An agent acting out of self-interest may be responsible for creating moral hazard, which can in turn disrupt the operation of the entire platform. This can happen if certain elements, that are provided by the platform owner, are used by an agent with malice and with intent to capture value. An agent can take different actions to pursue its self-interest:

- Hidden action: develop a parallel hierarchy in the system by deploying its own network of partners in competition with the principal.

- Hidden information: keep the fruits of its R\&D for itself, aiming to 
stall the development of the other players in the system in order to ensure its own strategic positioning.

- Port the developments in the context of one platform to another [competing] platform.

The platform owner cannot ignore these phenomena. Many platforms have disappeared or have been permanently destabilized. The example of IBM and Microsoft's tandem in the 1980s offers an outstanding illustration of creation of a parallel hierarchy. In 1981, Microsoft became IBM's new partner for the implementation of an operating system (D-DOS at the time, which was subsequently renamed into MS-DOS). The collaboration lasted for ten years, but since the very beginning Microsoft had secured an escape strategy by retaining the right to sell licenses to other manufacturers under the name of MS-DOS. Between 1981 and 1991 Microsoft had gradually expanded its network of partners working with the other industry giants such as Texas Instruments, Compaq, Thomson, Amstrad, etc..., and building on PC compatibility. Its platforms: MS-DOS and later Windows, enabled Microsoft to position itself at the heart of a vast network of partners. In 1991, IBM and Microsoft broke their original agreement and decided to develop their own operating systems: OS/2 and Windows, accordingly. We are all aware of the Microsoft's success, which was built at the IBM's expense. This divorce had weakened the IBM's system, which then struggled for several years in an effort to recover.

Solving agency problems requires actions on different levels. First, the platform owner must make its system transparent in order to enable itself to quickly detect harmful actions of some of its agents. Implementation of interoperability and property rights by platform owner may also be useful. Indeed, interoperability ensures a rapid and effective flow of innovations in the system. The platform owner may also take actions in an effort to keep its partners in a state of non-maturity: preventing its partners from growing ensures strong protection against agency problems. In other words, it is essential that the platform owner stays in control of links and relationships with its partners.

\subsection{The Second Determinant: Capitalization}

A firm that creates and runs a platform performs the function of a market. Its earnings find their origin in the exploitation of market failures. The 
platform fixes the problem of imperfect information by supplying information and missing knowledge to participating economic agents. As a result of so doing the transactions and exchanges emerge. The platform owner does not monetize on those interactions per se, but has a particular system of invoicing such that the participants are billed for the service of intermediation (percentage on every transaction, usage fee, membership fee).

The Apple's iPhone is an excellent example of control and capitalization. The AppStore, associated with the iPhone, is a platform that enables the iPhone users to download numerous applications to their mobile devices. Some of these applications are created by Apple while the majority of the applications are made available by its partners, the application developers. Hence, the AppStore plays the role of an intermediary: a market where the developers meet the consumers.

To ensure control of its platform, Apple employs several means. First, Apple requires that the developers use a specific software development kit $(\mathrm{SDK})^{1}$. This ensures some control over potential opportunistic behavior (hidden action) of the third-party developers: due to encoding specificity the applications written with this SDK can only run on Apple devices, and can be ported to non-Apple devices only if the developers re-code them. Another level of control appears very early in the relationship: developers can download the SDK free of charge, create applications, and test them on the iPhone simulator only after registering themselves with the AppStore. Finally, the distribution of all applications is done by Apple through the AppStore. Ex post, Apple exercises rigid control and scrutiny of all the available applications: it can choose to stop distribution of any application at any point in time if the application appears to be inappropriate. Some observers recorded several strategic bans by Apple (e.g. Netshare, or applications that mimic the iTunes functionalities).

Capitalization is two-tiered. First, the application can be made available to the end-users once the developer has paid the Apple Developer Connection membership fee (\$99 standard, \$299 enterprise). Second, Apple retains a 30\% commission of the application's sales, where the application's price is freely set by the application's developer.

Despite this, as of July 2011 the AppStore is a success with 15 billion app

\footnotetext{
${ }^{1}$ The SDK was first released on March, 6th 2008, to control the development and publishing of the third-party applications for iPhone.
} 
downloads and 425000 apps, available to 200 million iOS devices (iPhone, iPad and iPod Touch) in 90 countries. To date, Apple has paid the developers over $\$ 2,5$ billion.

\subsection{The Third Determinant: Interaction Type}

We view the firms' business activity to have its foundation in its interactions with its environment and observe the interaction types to be strategy depth-dependent. Interactions between firms-satellites and the central firm can either be competitive, cooperative, co-opetitive, exploitative (Peltoniemi (2006)), or neutral. To qualify the different types of interactions, we first define three levels of their potential effects:

Positive: the effect of interaction is beneficial to the firm (e.g.: increased profits, climbing market share, greater economic power, more advantageous position in the business ecosystem (BE), better reputation, etc...);

Negative: the effect of interaction is detrimental to the firm (e.g.: decreased profits, declined market share, plummeting economic power, disadvantageous position in BE, stained reputation, etc...);

Neutral: $\quad$ no effect on the firm.

Table 1: Interaction Effects

An interaction is a link between two firms. Interactions can be carried out through a formal (e.g. transactional or relational contract, (MacNeil $(1974))$ ), or informal relationship (e.g. externality). They can also have symmetric or asymmetric effects.

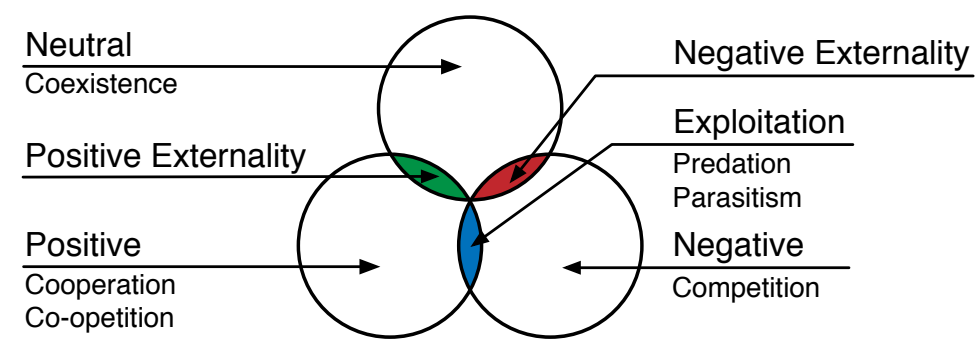

Figure 1: The Six Forms of Interaction 
The interfirm interaction effects can be formalized by outlining six distinct states, which are depicted in the figure 1 above.

Each interaction underlies specific economic situation, as described in the table 2 .

\begin{tabular}{|c|c|}
\hline INTERACTION TYPE & EFFECT \\
\hline Bilateraly Positive & $\begin{array}{l}\text { When both firms enjoy the positive effect, the link creates reciprocal and } \\
\text { beneficial relationship. Cooperation is a prominent example of this situation: } \\
\text { two firms pool resources together in order to complete a joint project that is } \\
\text { beneficial to both of them. All win/win situations will fall under this category. } \\
\text { Co-opetition is a special case: the negative effect created by competition is } \\
\text { overcompensated by the positive effect of cooperation, yielding a net positive } \\
\text { effect. }\end{array}$ \\
\hline$+1-$ & $\begin{array}{l}\text { Such link asymmetry is observed when one firm benefits from the interaction } \\
\text { while the other suffers the negative effect. The identity of the firm which } \\
\text { benefits is of key importance. In a case when the beneficiary is a platform } \\
\text { owner, two forms of asymmetric interaction may arise: predation or exploita- } \\
\text { tion. In the former, the platform owner uses its economic power to expel a } \\
\text { firm-satellite from its ecosystem through predatory behavior. In the latter, } \\
\text { the platform owner exploits the resources and competences of a firm-satellite, } \\
\text { thus bereaving it of the ability to reach maturity. As a result, the firm-satellite } \\
\text { is unable to develop its own business, hence suffering from the negative ef- } \\
\text { fect of interaction. Occasionally a firm-satellite is in a position to use the } \\
\text { resources and competences of the platform owner to create new business op- } \\
\text { portunities or innovative services. Although such link may appear to be a } \\
+/+ \text { interaction, in cases when firms-satellites extract and retain the entire } \\
\text { profit as a result of the interaction with the platform owner it is referred to } \\
\text { as parasitism. }\end{array}$ \\
\hline Bilateraly NEGATIVE & $\begin{array}{l}\text { Both firms suffer the negative effects of their interaction. Competition is but } \\
\text { a sole example of this situation. Competition compels the firms to abandon } \\
\text { (e.g.: price or quality wars) or to invest (e.g.: innovation) a part of their } \\
\text { profits in order to remain competitive and victorious over their rivals. }\end{array}$ \\
\hline Bilateraly Neutral & $\begin{array}{l}\text { Firms choose to neither compete, nor cooperate. The } 0 / 0-\text { or bilateraly } \\
\text { neutral - interaction involves no cooperation and no competition for resources } \\
\text { or customers; firms may exist within the confines of the same BE with no } \\
\text { links in common. As an example, consider the link neutrality between the } \\
\text { independent firms-satellites, given their simultaneous coexistence within the } \\
\text { same BE, such that it in no way affects the businesses of the participants. }\end{array}$ \\
\hline $\mathbf{0} /+$ or $0 /-$ & $\begin{array}{l}\text { One firm enjoys a positive (negative) effect while the effect on the other firm } \\
\text { is neutral. This is typically a situation of positive (negative) externality. The } \\
\text { activity of one firm creates a better (worse) economic environment for the } \\
\text { others, while the firm itself is neither positively, nor adversely affected. }\end{array}$ \\
\hline
\end{tabular}

Table 2: Classification of Interfirm Interactions

The above-discussed types of interactions have corresponding underlying strategies. Strategies can be profound or superficial in nature. Granovetter (1973) classifies interactions with respect to the strength of the ties that they yield; as such, non-equity alliances are characterized as ones having what Granovetter (1973) calls weak ties, whereas equity alliances are by definition the strong ties that require high initial investment, high level of commit- 
ment, and are characterized by intimate, recurrent and trustful relationships (Krackhardt (1992)). The interactions bearing weak ties are the indicators of exploratory strategy, whereas interactions with strong ties are by nature exploitative. The profound strategies are non-exploratory and are characterized by the participant's intent to permanently position themselves within the system. This can be identified by the firm's willingness to make significant investments to support and improve its position within the system.

\section{Effects of Firm/Market Equivalency on Industry Dynamics: the iPhone Case}

A prominent example of firm/market equivalency is the case of Apple iPhone's entry into the mobile industry. During the 1990's, before the emergence of $3 \mathrm{G}$ networks, capable of implementing mobile data services at a sufficient speeds, the mobile industry was highly dominated by mobile network operators and devices manufacturers. The former were controlling the access to customers while the latter were creating new phones able to fulfil customers' needs, e.g. voice telephony. The economic power in the industry was mostly in the hand of mobile network operators, who acted as gatekeepers (for access to consumers and control of value). Network operators possessed all the information about customers (usages, bills, identity, CRM, etc.) and were able to fix, to charge and to bill the services and content provided to customers. The content and service providers were remunerated by network operators, who used them to create a walled garden of services and content. Some operators even used exclusivity clauses with content providers and device manufacturers to differentiate themselves from competitors.

In the mid-2000s, the voice telephony revenues reached an inflexion point indicating the sector was entering a renewal phase. The phenomenon created pressure: the mobile operators started to fight against each other for market share. A price war was about to emerge. Handset manufacturers were asked to provide network operators with cheap and standardized devices. At the same time, mobile network operators started to invest huge amounts of money in their network to prepare for the $3 \mathrm{G}$ roll-out and the emergence of mobile Internet. Consumers were waiting for mobile Internet and its promises of ubiquitous Internet services. This mobile Internet failure is the starting point of Apple's success.

It is likely that Apple observed this market failure. Subsequently, it clearly changed the architecture of the mobile industry in two ways. First, 
it enabled its customers to experience the mobile device in a new manner by reincarnating the computer and fixed-line Internet experience. It hence leveraged consumers' willingness to access the entire Internet in a ubiquitous fashion. This created a breach of the boundary between mobile Internet (constructed by mobile network operators as a walled garden) and the Internet. Second, Apple was able to create sufficiently attractive platforms, AppStore and iTunes, to complement their device (iPhone) in an effort to compile its own system of developers and other third-party actors. The success of this endeavour is attributed to the following:

- Apple's economic dominance in the adjacent market (success of iPod and the iTunes platform) helped to project its economic power onto another market;

- The reputation, the brand, and the visionary CEO: Apple used its reputation, networks of partners and community of customers to enter the mobile market. Since 2002, shortly after the first release of the iPod, Steve Jobs was convinced that the next step will be to release a smartphone (with PDA, MP3 and other functionalities).

Naturally, Apple used both of the above-mentioned elements to convince AT\&T and other operators to cooperate with them. Network operators seemed to be unable to launch the mobile Internet and to ensure sufficient returns to cover their huge investments in $3 \mathrm{G}$. The iPhone was an efficient beacon for new customers and an attractive upgrade device for the existing ones. For instance, in the US, the introduction of iPhone allowed AT\&T to simultaneously increase its market share and average revenue per user. However, this cooperation with Apple had a price tag of its own: Apple succeeded by obtaining direct access to the consumers through direct billing and CRM via the iTunes. Apple changed the industry rules by creating a breach in the mobile value chain: it forced a change in the balance of power in favor of the device manufacturers.

Apple's entry into the mobile industry can be interpreted in a number of ways. Following the point of view of the network operators (the former leaders), Apple entered the market in a cooperative way, helping them to create a profitable mobile Internet in exchange for obtaining a part of the control on consumers and innovation. In this sense, the network operators lost their gatekeeper roles and a part of their economic power in the industry. For the third-party developers, Apple's move appears to be a good attempt to break 
the walled garden of mobile operators, propose new services and content to consumers, and gain access to a part of the mobile Internet pie. Moreover, for non-developers Apple creates new advertising and distribution media (game manufacturers, brands, charities, newspaper, TV channels, etc.) via the AppStore. For the device manufacturers, the entry of Apple was clearly an aggression since it enhanced competition by de novo entrants (Google, Microsoft) and de alio (He et al. (2006)) entrants (RIM, Palm/HP). De novo entrants came from the adjacent industries (PC, Internet). De alio entrants (Personal Digital Assistant industry) were operating in niches within the mobile industry. With success of the iPhone, smartphones became popular and are no longer in a niche, forcing incumbent to adapt.

Table 3 offers a visualization of the different types of interactions between Apple and other players in the mobile industry.

\begin{tabular}{|c|c|c|c|}
\hline Players of Mobile Industry & \multicolumn{2}{|c|}{ Interaction With Apple } & $\begin{array}{l}\text { IMPACT ON APPLE ECOSYSTEM } \\
\text { AND PLATFORMS }\end{array}$ \\
\hline $\begin{array}{l}\text { Network operators } \\
\text { (former leaders of mobile BEs) }\end{array}$ & $+/+$ & Cooperation & $+(3 \mathrm{G}$ roll-out $)$ \\
\hline $\begin{array}{l}\text { Device manufacturers } \\
\text { (wannabe leaders) }\end{array}$ & $-/-$ & Competition & $\begin{array}{l}- \text { (Competition) } \\
+ \text { (Enhance the market for } \\
\text { smartphones })\end{array}$ \\
\hline Developers & $+/+$ & Cooperation & $\begin{array}{l}+ \text { (Enhance the value of the } \\
\text { platform })\end{array}$ \\
\hline Non-developers & $+/+$ & $\begin{array}{l}\text { or } 0 /- \\
\text { Cooperation } \\
\text { Negative externalities }\end{array}$ & $\begin{array}{l}+ \text { (For games or other services } \\
\text { that enhance the use of the } \\
\text { iPhone) } \\
0 /- \text { (When iPhone is used as } \\
\text { an advertising device) }\end{array}$ \\
\hline
\end{tabular}

Table 3: Apple Interactions

From the above discussion, we argue that Apple is clearly in the context of firm/market equivalency. It used this strategy to counterbalance the power of network operators and change the hierarchy in the industry. Apple enjoys a huge network of partners around its platforms (AppStore and iTunes). As a consequence, network operators start to experience decreasing control over consumers and device manufacturers. However, even though Apple has not taken the lead in the industry in terms of volume of mobile devices sold ${ }^{2}$, it changed the rules of the game in the industry by rebalancing the economic

\footnotetext{
${ }^{2}$ It is noteworthy that although Apple's mobile market share is only $4 \%$, the profits that the iPhone pulls in account for over $50 \%$ of the industry's profits (The Economist (2011)).
} 
power and changing the overall architecture.

Since then the mobile industry is punctuated by a rapid pace of innovation. Within the past few years the software vendors, OS providers, device manufacturers, and network operators have had launched their own versions of application stores (markets). Apple's iPhone and its AppStore marked the end of a business cycle in the mobile industry forcing other players to imitate it: OviStore (Nokia), Android Market (Google), AppCatalog (Palm), Windows Marketplace (Microsoft), AppWorld (BlackBerry). Meanwhile, MNOs realized that the world is changing and that they have to push their own standards for applications in search for new revenues and a certain degree of control over their networks. Yet, some of them are considering appstores as a way to generate cash, selling applications that include the bandwidth needed to use them. They are also trying to provide web-based services (Widgets, Mashups), third party services (social search or recommendation tools) or capabilities to others (long tail content).

Apple has forced the whole industry to exit its decline phase and to enter a renewal phase. The industry is now in a transitory period with no real leadership and full expansion. Network operators had lost some economic power, but they gained profits. They are still controlling the network and hence the speed, the security, and the quality of data transmission. Moreover, wireless and fixed-line sector have initiated their convergence. The transition will probably last several years until the emergence of the $4^{\text {th }}$ or even $5^{\text {th }}$ generation of mobile network.

\section{Concluding Comments: Antitrust Issues}

Economic players developing a firm/market equivalency model hold a significant market power on the market created: they control the entry and exit of players, their activities, the financial flows, the innovation process, the resources provided, the flow of knowledge, the structure of the market, its dynamics and the interactions among players. In other words, they exert a perfect control of the competition process in their markets. By acting as intermediaries or market support, these firms suffer no competitive pressure from their partners acting on their own markets.

Following the European competition case law, a firm in a dominant position has the ability to behave independently of its competitors, suppliers and final consumers. A dominant firm has a special responsibility towards its market: its conduct should not distort competition. As such, a dominant 
position per se is not forbidden, but any abuse is prohibited. In this sense, a firm operating a firm/market equivalency should then be regarded as dominant in its market(s). Hence, any exclusion of partners or any strategic move eliminating some players and changing market dynamics can be interpreted as abuse of the dominance position.

However, dominance is appreciated in a relevant market, which can be hard to define in the context of firm/market equivalency. The structure of firm/market equivalency involves existence of a central firm and its products, surrounded by complementary and adjacent products or services, that are provided by its partners. As an intermediary, the central firm exerts market power on the structure, and this structure is in competition with the other structures of its kind. For instance, the whole system of Microsoft's operating system (Windows) is in competition with the whole system of Apple's operating system (Mac OS X) as well as with the operating system of Google (Android). In such situation many questions arise: is there one relevant market for each operating system? Is there a relevant market of an operating system? Is there a market for each complementary good (for instance: web browser or media player) on each operating system? The case law seems to follow the latter, segregating each system into separate relevant markets, where the central players are, by construction, the dominant players. However, it is hard to deny the presence of competitive pressure exerted by Google and Apple on Microsoft. In the mobile sector none of them can be referred to as dominant.

The key difference lies in the attitude of small players. In the mobile sector they multi-home: the small players intervene in different systems by re-coding applications. In such case, the central players still exert some degree of control, but small players impose competitive pressure on each system through their strategic behavior. These strategies can be comprehended by the indepth study of their interactions (relationships): such analysis may provide further insight when the analysis of the antitrust cases is concerned, and may aid in assessment of the market power of firms developing firm/market equivalency model.

Innovation is at the heart of new technologies and their development. Apple, Google and other players have developed firm/market equivalency strategies for innovation. These firms create incubator-like structures in which they give access to their knowledge, skills, competences and other resources to smaller partners, who are often more dynamic and sometimes more innovative. The like of this system has previously been referred to as 
co-opetition or collective invention. But here the system goes farther: the central firm scrutinizes it, perfectly controls it and at any given moment can absorb an attention-drawing innovation into its platform or choose to diffuse it throughout the system. In this case, the system performs two social objectives: (1) it fosters the increase in probability of emergence of an innovation though opening up the resources and the intellectual property of the central firm, as well as (2) it contributes to diffusion of innovation. These collaborative models of innovation improve the process of the innovation genesis in our society. However, it is likely that these systems of markets for innovation could have been created in an effort to protect central firms against the threat of disruptive innovations, which may damage the central firms' existing markets. Central firms possess the power to use their position in order to block, postpone or destroy innovative services or products, which in turn may negatively affect the overall innovation process. The latter case may call for antitrust intervention. Again, analysis of interactions of market players may facilitate the analysis of these kinds of cases.

\section{References}

Armstrong, M. (2006), Competition in Two-Sided Markets, RAND Journal of Economics, 37(3):668-691.

Bator, F. (1958), The Anatomy of Market Failure, Quarterly Journal of Economics, 72(3):351-379.

Baumol, W., Panzar, J., and Willig, R. (1982). Contestable Markets and the Theory of Industrial Structure. Harcourt, Brace, Jovanovich, New York.

Cassady, R. (1967). Auctions and Auctioneering. University of California Press, Berkley and Los Angeles, California.

Cusumano, M. (2010). Staying Power: Six Enduring Principles for Managing Strategy and Innovation in an Uncertain World. Oxford University Press, USA.

Dundas, K., and Richardson, P. (1980), Corporate Strategy and the Concept of Market Failure, The Strategic Management Journal, 1(2):177-188.

Evans, D., Hagiu, A., and Schmalensee, R. (2006). Invisible Engines: How Software Platforms Drive Innovation and Transform Industries, 1st Edition. MIT Press, Cambridge, MA. 
Gawer, A. (2009). Platforms, Markets and Innovation. Edward Elgar Publishing Ltd., Cheltenham, UK and Northampton, MA, US, Ch. Platform Dynamics and Strategies: From Products to Services, p. 416.

Granovetter, M. (1973), The Strength of Weak Ties, American Journal of Sociology, 78(6):1360-1380.

He, Z.-L., Lim, K., and Wong, P.-K. (2006), Entry and Competitive Dynamics in the Mobile Telecommunications Market, Research Policy, 35(2006):1147-1165.

Iansiti, M., and Levien, R. (2004). The Keystone Advantage: What the New Dynamics of Business Ecosystems Mean for Strategy, Innovation, and Sustainability. Harvard Business School Press, Boston.

Krackhardt, D. (1992). Networks and Organizations: Structure, Form, and Action. Harvard Business School Press, Ch. The Strength of Stong Ties: The Importance of Philos in Organizations, pp. 216-239.

MacNeil, I. (1974), The Many Futures of Contracts, South California Law Review, 47(5):691-816.

McAfee, R., Mialon, H., and Williams, M. (May 2004), When are Sunk Costs Barriers to Entry? Entry Barriers in Economic and Antitrust Analysis, American Economic Review, 94(2):461-465.

Moore, J. (May-June 1993), Predators and Prey: A New Ecology of Competition, Harvard Business Review:75-86.

Moore, J. (1996). The Death of Competition: Leadership and Strategy in the Age of Business Ecosystems. Harper Business, New York.

Moore, J. (1997). The Death of Competition: Leadership and Strategy in the Age of Business Ecosystems. Harper Paperbacks.

Moore, J. (Spring 2006), Business Ecosystems and the View from the Firm, Antitrust Bulletin, 51(1):31-75.

Peltoniemi, M. (2006), Preliminary Theoretical Framework for the Study of Business Ecosystems, Emergence: Complexity \& Organization, 8(1):10-19. 
Rochet, J., and Tirole, J. (2003), Platform Competition in Two-Sided Markets, Journal of the European Economic Association, 1(4):990-1029.

Rochet, J., and Tirole, J. (2006), Two-Sided Markets: A Progress Report, RAND Journal of Economics, 37(3):645-667.

Rysman, M. (2009), The Economics of Two-Sided Markets, Journal of Economic Perspectives, 23(3):125-143.

Stewart, T. (April 2008), Magic by Design, Harvard Business Review:14.

The Economist (February 2011), Nokia at the Crossroads: Blazing Platforms, The Economist, 398(8720):69-70.

Weyl, E. (2010), A Price Theory of Multi-sided Platforms, American Economic Review, 100(4):1642-1672.

Williamson, O. (1975). Markets and Hierarchies: Analysis and Antitrust Implications. The Free Press, New York. 